\title{
The Doublecortin-Expressing Population in the Developing and Adult Brain Contains Multipotential Precursors in Addition to Neuronal-Lineage Cells
}

\author{
Tara L. Walker, ${ }^{1}$ Takahiro Yasuda, ${ }^{1,2}$ David J. Adams, ${ }^{2}$ and Perry F. Bartlett ${ }^{1}$ \\ ${ }^{1}$ Queensland Brain Institute and ${ }^{2}$ School of Biomedical Sciences, The University of Queensland, Brisbane, Queensland 4072, Australia
}

\begin{abstract}
Doublecortin (DCX) has recently been promulgated as a selective marker of cells committed to the neuronal lineage in both the developing and the adult brain. To explore the potential of DCX-positive $\left(\mathrm{DCX}^{+}\right)$cells more stringently, these cells were isolated by flow cytometry from the brains of transgenic mice expressing green fluorescent protein under the control of the DCX promoter in embryonic, early postnatal, and adult animals. It was found that virtually all of the cells $(99.9 \%)$ expressing high levels of DCX (DCX $\left.{ }^{\text {high }}\right)$ in the embryonic brain coexpressed the neuronal marker $\beta$ III-tubulin and that this population contained no stem-like cells as demonstrated by lack of neurosphere formation in vitro. However, the $\mathrm{DCX}^{+}$population from the early postnatal brain and the adult subventricular zone and hippocampus, which expressed low levels of $\mathrm{DCX}\left(\mathrm{DCX}^{\mathrm{low}}\right)$, was enriched for neurosphere-forming cells, with only a small subpopulation of these cells coexpressing the neuronal markers $\beta$ III-tubulin or microtubule-associated protein 2 . Similarly, the DCX ${ }^{\text {low }}$ population from embryonic day 14 (E14) brain contained neurosphere-forming cells. Only the postnatal cerebellum and adult olfactory bulb contained some DCX ${ }^{\text {high }}$ cells, which were shown to be similar to the E14 DCX ${ }^{\text {high }}$ cells in that they had no stem cell activity. Electrophysiological studies confirmed the heterogeneous nature of $\mathrm{DCX}^{+}$cells, with some cells displaying characteristics of immature or mature neurons, whereas others showed no neuronal characteristics whatsoever. These results indicate that DCX ${ }^{\text {high }}$ cells, regardless of location, are restricted to the neuronal lineage or are bone fide neurons, whereas some $\mathrm{DCX}^{\text {low }}$ cells retain their multipotentiality.
\end{abstract}

Key words: doublecortin; precursor; transgenic; neurogenesis; neuroblast; adult and developing brain

\section{Introduction}

Doublecortin (DCX) is a $40 \mathrm{kDa}$ microtubule-associated protein (MAP) that is expressed in a precise temporal manner in migrating neuroblasts during early embryonic development. It is also retained in neurogenic areas in the adult (the subventricular zone (SVZ)/rostral migratory stream/olfactory bulb axis and the dentate gyrus of the hippocampus), a pattern that suggests it is an ideal marker of both embryonic corticogenesis and adult neurogenesis (Francis et al., 1999; Rao and Shetty, 2004; CouillardDespres et al., 2005). High DCX expression (DCX ${ }^{\text {high }}$ ) occurs transiently during the early stages of corticogenesis, with the highest levels of expression being observed at embryonic day 14 (E14), before decreasing to low levels by birth (des Portes et al., 1998; Francis et al., 1999; Hannan et al., 1999; Meyer et al., 2002; Brown et al., 2003; Lee et al., 2005). Moreover, the protein is not reexpressed during gliogenesis or regenerative axonal growth (Couillard-Despres et al., 2005), confirming its selectivity for

Received July 6, 2006; revised Feb. 5, 2007; accepted Feb. 22, 2007.

This study was funded by a National Health and Medical Research Council program grant (P.F.B.). We thank Prof. Peter Jeffrey (Children's Medical Research Institute, Sydney, Australia) for his donation of the pBluescript-DCX construct, Transgenic Animals Services Queensland for the pronuclear injections to generate the DCX-GFP mouse lines, and the staff at the University of Queensland School of Biomedical Sciences Animal Facility for maintaining and breeding the animals used in this study.

Correspondence should be addressed to Perry Bartlett, Queensland Brain Institute, The University of Queensland, Brisbane, Queensland 4072, Australia. E-mail: p.bartlett@uq.edu.au.

DOI:10.1523/JNEUROSCI.5060-06.2007

Copyright $\odot 2007$ Society for Neuroscience $\quad$ 0270-6474/07/273734-09\$15.00/0 newly born neurons and not later neuronal regenerative events. The restriction of DCX expression to the neuronal precursor phase of the neuronal lineage has also been further suggested (Brown et al., 2003) by its lack of colocalization with nestin, a marker of multipotential precursors.

The lack of useful stage-specific markers has made the characterization of lineage-specific cell types difficult. However, the generation of transgenic mice expressing reporter genes such as green fluorescent protein (GFP) under the control of cell typespecific promoters now provides a source of cells suitable for lineage interrogation both in vivo and in vitro. Examples include the neural precursor-specific markers nestin (Frisen et al., 1995) and glial fibrillary acidic protein (GFAP) (Nolte et al., 2001), the pan-neuronal marker tubulin $\alpha 1$ (Gloster et al., 1994), the neuronal precursor-specific pro-opiomelanocortin (Overstreet et al., 2004), and the oligodendroglial marker $2^{\prime} 3^{\prime}$-cyclic nucleotide $3^{\prime}$-phosphodiesterase (Gravel et al., 1998).

In this study, we used two strains of DCX-GFP transgenic mice to isolate and characterize DCX-positive $\left(\mathrm{DCX}^{+}\right)$cells. This has revealed that virtually all cells expressing high levels of DCX are restricted to the neuronal lineage, whereas the population that expresses low levels of DCX (DCX $\left.{ }^{\text {low }}\right)$ contains a significant number of multipotential precursors.

\section{Materials and Methods}

Generation of DCX-GFP/2 kb transgenic mice

A construct containing $2 \mathrm{~kb}$ of the mouse DCX promoter, from -1802 to

+199 bp relative to the translation start site in the plasmid pBluescript, 
was obtained from Prof. Peter Jeffrey (Children's Medical Research Institute, Sydney, New South Wales, Australia). A fragment containing the enhanced GFP gene (eGFP) and the simian virus 40 poly(A) was removed from plasmid pEGFP1 (BD Biosciences Clontech, Heidelberg, Germany) by digestion with SalI and AflII and blunt ending the AflII site with Klenow. Unless otherwise noted, all enzymes were obtained from New England Biolabs (Frankfurt, Germany). The fragment containing the eGFP gene was cloned into SalI and BfrBI-digested pBS-DCX to generate the clone pDCXeGFP. Plasmid DNA was purified using the plasmid maxiprep kit (Qiagen, Melbourne, Victoria, Australia), after which the DCXeGFP cassette was removed by digestion of $40 \mu \mathrm{g}$ of DNA with SpeI, BsrBI, and XmnI. Digested DNA was run on a $0.7 \%$ Tris borate-EDTA gel, and the insert was purified using the Qiagen gel purification kit. Transgenic mice (DCX-GFP/2 kb) were generated by pronuclear injection of the DNA cassette into fertilized BCBF1 mouse eggs, which were then implanted into pseudopregnant animals. DNA was isolated from the resulting offspring, and founder mice were identified via PCR using primers DCXP2009F (5' -CAGAACCAGAACCTTGCAGGC$3^{\prime}$ ) and eGFPR2 (5'-GCGCGGGTCTTGTAGTTGCCG-3'). The PCR conditions were one cycle of $94^{\circ} \mathrm{C}$ for $3 \mathrm{~min}$, followed by 40 cycles of $94^{\circ} \mathrm{C}$ for $30 \mathrm{~s}, 60^{\circ} \mathrm{C}$ for $30 \mathrm{~s}$, and $72^{\circ} \mathrm{C}$ for $30 \mathrm{~s}$, with a final cycle of $72^{\circ} \mathrm{C}$ for 7 min. A second DCX-GFP transgenic mouse [DCX-GFP/bacterial artificial chromosome (BAC)] was obtained from the Mutant Mouse Regional Resource Center, The Gene Expression Nervous System Atlas BAC transgenic project (Gong et al., 2002). Lineages of founder mice were established by breeding transgenic animals with wild-type C57BL/6 mice. Animals were treated in accordance with the Australian Code of Practice for the Care and Use of Animals for Scientific Purposes, and all experiments were approved by the University of Queensland Animal Ethics Committee.

\section{Immunohistochemical analysis of GFP and DCX expression in transgenic tissue sections}

Experiments were performed on embryonic day 14 (E14) and postnatal day 2 (P2) pups using either the DCX-GFP/2 kb or DCX-GFP/BAC transgenic strain, whereas those experiments performed on adult tissue made use of the DCX-GFP/BAC animal. Adult C57BL/6 mice were time mated to heterozygous DCX-GFP transgenic animals. The brains from E14 embryos or P2 pups were immediately dissected and fixed in $4 \%$ paraformaldehyde (PFA) in $0.1 \mathrm{M}$ PBS for $3 \mathrm{~h}$ at $4^{\circ} \mathrm{C}$. Adult animals were perfused with $0.1 \mathrm{~m}$ PBS followed by $4 \%$ PFA. The brains were then removed and incubated overnight in 4\% PFA, followed by an additional overnight incubation in $15 \%$ sucrose in $0.1 \mathrm{M}$ PBS. They were subsequently incubated in 1:1 (v/v) 15\% sucrose/optimal cutting temperature compound (OCT) and then in 100\% OCT before being snap frozen in OCT and stored at $-80^{\circ} \mathrm{C}$. Coronal and sagittal sections $(15 \mu \mathrm{m})$ were cut on a cryostat (Leica, Wetzlar, Germany) and collected onto glass slides. Sections were postfixed in $4 \%$ PFA for $5 \mathrm{~min}$ and washed briefly in PBS before being incubated for $60 \mathrm{~min}$ at room temperature with blocking solution: $5 \%$ fetal calf serum (FCS) (JHR Biosciences, Brooklyn, Victoria, Australia) plus 5\% normal goat serum (NGS) (Sigma, Sydney, New South Wales, Australia) in 0.1 m PBS containing $0.1 \%$ Triton X-100 (Sigma). The blocking solution was then replaced with fresh blocking solution containing guinea pig anti-DCX antibody (1:200; Millipore, Temecula, CA), and the sections were incubated either for $60 \mathrm{~min}$ at room temperature or at $4^{\circ} \mathrm{C}$ overnight, after which they were washed with PBS and incubated for $40 \mathrm{~min}$ at room temperature in blocking solution containing Alexa Fluor 546 goat anti-guinea pig antibody (1: 1000; Invitrogen, Carlsbad, CA) and 4',6-diamidino-2-phenylindole (DAPI) (1:1000; Invitrogen). After washing with PBS, the slides were coverslipped with fluorescence mounting medium (Dako Cytomation, Carpinteria, CA) before viewing on an Olympus Optical (Brisbane, Queensland, Australia) upright fluorescence microscope. Images were captured by a digital camera linked to a computer running analySIS software (Olympus Optical).

\section{Fluorescence-activated cell sorting and generation of primary} neurosphere and neuronal cultures

E14, P2, and adult brains were collected as described above and either processed whole or dissected into specific regions (olfactory bulb, cortex, cerebellum, and SVZ). GFP ${ }^{+}$cells were separated by fluorescenceactivated cell sorting (FACS) using an FACS Vantage cell sorter (BD Biosciences, San Jose, CA). A wild-type littermate control was used to determine background fluorescence levels. For primary neurosphere cultures, the cells were plated at a density of 500 cells per well in 96-well plates (BD Falcon, San Jose, CA) with $0.2 \mathrm{ml}$ of complete medium per well. Complete medium consisted of mouse NeuroCult NSC Basal Medium plus mouse NeuroCult NSC Proliferation Supplements (StemCell Technologies, Vancouver, British Columbia, Canada) with 2\% bovine serum albumin (Roche, Basel, Switzerland) and $2 \mu \mathrm{g} / \mathrm{ml}$ heparin (Sigma). The following growth factors were also included: $20 \mathrm{ng} / \mathrm{ml} \mathrm{pu-}$ rified mouse receptor-grade epidermal growth factor (BD Biosciences, North Ryde, New South Wales, Australia) and $10 \mathrm{ng} / \mathrm{ml}$ recombinant bovine basic fibroblast growth factor (Roche). Primary cells were incubated for $7 \mathrm{~d}$ in humidified $5 \% \mathrm{CO}_{2}$ to permit neurosphere formation. The primary neurospheres were then counted and collected for passaging or differentiation. Results of the neurosphere counts were expressed as mean $\pm \mathrm{SE}$, and statistical analysis was performed using a standard $t$ test (two sample assuming equal variance).

\section{Neurosphere passaging and differentiation}

Neurospheres were collected after $7 \mathrm{~d}$ and passaged as described previously (Bull and Bartlett, 2005). The passaged cells were then replated with $2 \mathrm{ml}$ of complete medium at a density of 20,000 cells per well in 24-well tissue culture plates (Falcon). Neurospheres were passaged every $7 \mathrm{~d}$ for up to 12 passages, after which they were differentiated for $5 \mathrm{~d}$ and then stained for the neuronal marker $\beta$ III-tubulin and the astrocytic marker GFAP with a DAPI counterstain (see below).

\section{Immunocytochemistry of DCX-GFP cells and FACS analysis}

Brains were dissected from E14, P2, or adult DCX-GFP mice and then dissociated and resuspended in $875 \mu \mathrm{l}$ of cold PBS. Cells were fixed by incubation with $62.5 \mu \mathrm{l}$ of cold $4 \%$ PFA for $30 \mathrm{~min}$ at $4^{\circ} \mathrm{C}$. They were then pelleted by centrifugation at 104 relative centrifugal force for $7 \mathrm{~min}$ and permeabilized using $1 \mathrm{ml}$ of PBS containing $0.2 \%$ Tween 20 (Sigma) with an incubation period of $15 \mathrm{~min}$ at $37^{\circ} \mathrm{C}$. After blocking for $30 \mathrm{~min}$ at $4^{\circ} \mathrm{C}$ in PBS containing 2\% FCS, the cells were incubated in primary antibodies: $\beta$ III-tubulin (1:1000, mouse monoclonal; Promega, Madison, WI), MAP2ab (1:250, mouse monoclonal; Neomarkers, Fremont, CA), nestin (1:250, mouse monoclonal; Millipore), Ki-67 (1:250, mouse monoclonal; BD PharMingen, San Diego, CA), Dlx2 (distal-less homeobox 2) (1:250, rabbit polyclonal; Millipore), GFAP (1:500, rabbit polyclonal; Dako Cytomation), or DCX (1:250, guinea pig polyclonal; Millipore) for $30 \mathrm{~min}$ at $4^{\circ} \mathrm{C}$. Primary antibody was removed by washing the cells once in $1 \mathrm{ml}$ of blocking solution ( $2 \%$ FCS, $2 \%$ NGS, and $0.1 \%$ Triton X-100) before incubating at $4^{\circ} \mathrm{C}$ for $30 \mathrm{~min}$ in $200 \mu \mathrm{l}$ of secondary antibody [1:1000 dilution of anti-mouse phycoerythrin (PE) (BD Biosciences, San Jose, CA) or anti-rabbit PE (Invitrogen)]. The cells were then washed in PBS before being resuspended in $1 \mathrm{ml}$ of PBS for analysis by FACS. Cells stained with secondary antibody alone were used as a background control for determining the negative gates. For polysialylated neural cell adhesion molecule (PSA-NCAM) staining, cells were incubated for $30 \mathrm{~min}$ in anti-PSA-NCAM (1:500, mouse monoclonal; Millipore) and then washed and incubated for $30 \mathrm{~min}$ in AlexaFluor 633 anti-mouse IgM (1:700; Invitrogen). Cells were analyzed using a FACS Vantage cell sorter (BD Biosciences, San Jose, CA) or an ImageStream 100 (Amnis, Seattle, WA).

\section{Electrophysiological methods}

Acute brain slice preparation. Whole brains were dissected and placed in ice-cold, $95 \% \mathrm{O}_{2} / 5 \% \mathrm{CO}_{2}$-saturated artificial CSF (aCSF) composed of the following (in mM): $126 \mathrm{NaCl}, 2.5 \mathrm{KCl}, 2.4 \mathrm{CaCl}_{2}, 1.2 \mathrm{MgCl}_{2}, 1.2$ $\mathrm{Na}_{2} \mathrm{HPO}_{4}, 26 \mathrm{NaHCO}_{3}$, and 10 glucose at $\mathrm{pH}$ 7.4. Coronal forebrain (E14, P2, and adult $>3$ weeks) or hippocampal (adult $>3$ weeks) slices of $300-400 \mu \mathrm{m}$ thickness were cut in cold aCSF using a vibratome (Vibroslice; World Precision Instruments, Sarasota, FL). Slices were then stored in oxygenated aCSF at room temperature for $>1 \mathrm{~h}$ to allow recovery.

Electrophysiological recordings. DCX-GFP ${ }^{+}$cells were identified in acute brain slices. Whole-cell current and voltage-clamp recordings were obtained from these cells using an Axopatch 200B patch-clamp amplifier (Molecular Devices, Union City, CA). Data were acquired at $5-10 \mathrm{kHz}$ 
and filtered at $2-5 \mathrm{kHz}$ with a Digidata 1320 interface (Molecular Devices), linked to a personal computer equipped with pClamp 9.0 software (Molecular Devices). Whole-cell capacitance was compensated and leak currents were subtracted during voltage clamp recordings. The liquid junction potential was not corrected. Patch electrodes, which were pulled from borosilicate glass capillaries, had resistances of 1.5-4 $\mathrm{M} \Omega$ when filled with pipette solution. For slice patch recordings, a coronal forebrain slice was placed in a submersion recording chamber, in which it was held in position by nylon threads attached to a U-shaped platinum wire and continuously perfused with oxygenated aCSF at a rate of $\sim 5 \mathrm{ml} / \mathrm{min}$. Dialyzed whole-cell patch-clamp recordings were performed using a pipette solution containing the following (in $\mathrm{mm}$ ): $130 \mathrm{KCl}, 5 \mathrm{NaCl}, 0.4$ $\mathrm{CaCl}_{2}, 1 \mathrm{MgCl}_{2}, 1.1 \mathrm{EGTA}$, and $10 \mathrm{HEPES}-\mathrm{NaOH}$ at $\mathrm{pH}$ 7.3. For dialyzed or perforated patch-clamp recordings from cultured $\mathrm{DCX}^{+}$cells, cells attached to a glass coverslip were placed in a recoding chamber and continuously perfused at a rate of $\sim 1 \mathrm{ml} / \mathrm{min}$ with the following extracellular recording solution (in mM): $140 \mathrm{NaCl}, 3 \mathrm{KCl}, 2 \mathrm{CaCl}_{2}, 1 \mathrm{MgCl}_{2}$, 10 HEPES-NaOH, and 10 glucose at $\mathrm{pH}$ 7.4. The pipette solution for cultured $\mathrm{DCX}^{+}$cells contained the following (in mM): $145 \mathrm{KCl}, 5 \mathrm{NaCl}$, and 10 HEPES-NaOH, pH adjusted to 7.2. For perforated patch-clamp recordings, the patch electrode was filled with an intracellular solution containing $240 \mathrm{~g} / \mathrm{ml}$ amphotericin B. However, there was no apparent difference in the electrical properties of cells recorded under either dialyzed or perforated patch configurations. Experiments were performed at room temperature (E14 and P2) or $30-32^{\circ} \mathrm{C}$ (adult). Cell capacitance $\left(C_{\mathrm{m}}\right)$ was measured by integrating the capacitative transient evoked during a $10 \mathrm{mV}$ depolarizing step from a holding potential of $-70 \mathrm{mV}$. Resting membrane potential (RMP) and input resistance $\left(R_{\mathrm{in}}\right)$ were determined from current-clamp recordings in the absence and during a hyperpolarizing current pulse of $10-200 \mathrm{pA}$, respectively. Data were analyzed using Clampfit 9.2 and Prism 4.0 (GraphPad, San Diego, CA).

\section{Results}

\section{GFP expression colocalizes with native DCX expression in} brain of embryonic and postnatal DCX-GFP transgenic mice Of the 11 founder lines examined for the DCX-GFP/2 kb transgenic strain, only one displayed high levels of GFP expression. To ensure that this GFP expression colocalized with DCX protein expression, sections were stained with an anti-DCX antibody. At E14, we found that $\mathrm{GFP}^{+}$cells predominantly coincided with DCX staining in the neopallatial cortex (the future cerebral cortex), the diencephalon (thalamus), and the intermediate zone of the lateral and medial ganglionic eminences (striatum) (Fig. $1 \mathrm{~A}-$ $F$ ). Strong coexpression was also observed in the embryonic spinal cord. No expression or staining was observed in either the ventricular zone of the telencephalon or the ventricular zone of the ganglionic eminence.

In postnatal sections, the level of GFP expression was lower than that observed in the embryo but was again restricted to regions stained with DCX antibody. There was extensive labeling in the cortical plate and the intermediate zone regions, as well as in the hippocampus and olfactory bulb, with strong expression in the cerebellum. However, in the DCX-GFP/2 kb transgenic strain, no GFP expression or staining with an anti-GFP antibody could be detected in the adult (data not shown). This led us to examine a second strain DCX-GFP/BAC in which GFP was inserted into a BAC clone (RP23-462G16) just upstream of the DCX coding region. This animal had strong GFP expression in the dentate gyrus of the hippocampus, the SVZ, the rostral migratory stream, and the olfactory bulb (Fig. $1 \mathrm{H}, \mathrm{K}$ ), and this expression was found to colocalize with immunostaining for DCX (Fig. $1 G, I, J)$.

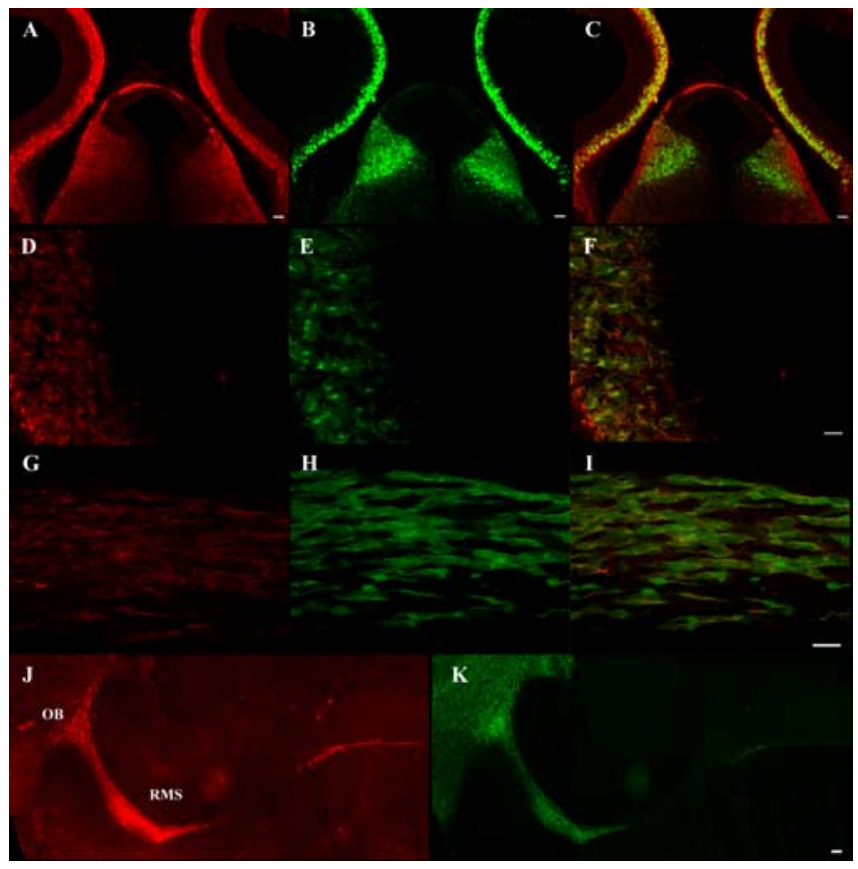

Figure 1. $D C X$ and GFP expression colocalize in DCX-GFP transgenic mouse lines. $\boldsymbol{A}-\boldsymbol{K}$, In transgenic DCX-GFP/2 kb brain sections GFP ${ }^{+}$cells are found in the E14 cortex and thalamus $(\boldsymbol{A}-\boldsymbol{C})$ and in the cortex $(\boldsymbol{D}-\boldsymbol{F})$ in a pattern that colocalized with $D C X$ staining. In the adult $D C X-G F P / B A C$ line, GFP expression was observed in the rostral migratory stream (RMS) and olfactory bulb $(O B)(H, K)$ in a pattern that coincides with native $D C X$ staining $(G, I, J)$. Scale bars: $A-C, J, K, 1 \mathrm{~mm} ; \boldsymbol{D}-I, 100 \mu \mathrm{m}$.

\section{GFP intensity reflects the level of DCX expression in individual cells}

To confirm that the GFP intensity accurately reflected the level of DCX expression in individual cells, cells were isolated from both transgenic strains, stained with a DCX-specific antibody, and analyzed by FACS. For the DCX-GFP/2 kb transgenic mouse, cells from E14 whole brain were analyzed, whereas for the BAC strain cells from the adult SVZ were used. Analysis of this colabeling using the ImageStream 100 clearly showed that the GFP intensity accurately reflected the level of endogenous DCX expression in single cells (Fig. 2). Cells with high DCX expression also expressed high levels of GFP protein, but, more importantly, all cells lacking GFP expression showed an absence of DCX staining and no false GFP positives were detected.

\section{Defining the characteristics of DCX-expressing cells at} different developmental stages and in different brain regions We examined the DCX-expressing populations at various stages of development to determine whether the characteristics of cells expressing similar DCX levels varied with age or had some common features.

\section{At E14, DCX expression levels define a neuronally restricted population}

To determine the lineage restriction and proliferative potential of $\mathrm{DCX}^{+}$cells during early neurogenesis, $\mathrm{GFP}^{+}$cells were isolated from E14 brains from both the DCX-GFP/2 kb and DCX-GFP/ BAC lines by FACS. At this developmental age, these cells comprised $\sim 40 \%$ of the total population. For additional analysis, the E14 $\mathrm{DCX}^{+}$cell population was gated into three equal populations; these were designated high, mid ( $\mathrm{DCX}^{\mathrm{mid}}$ ), and low based on DCX expression (Fig. 3A). For each experiment, unsorted cells 


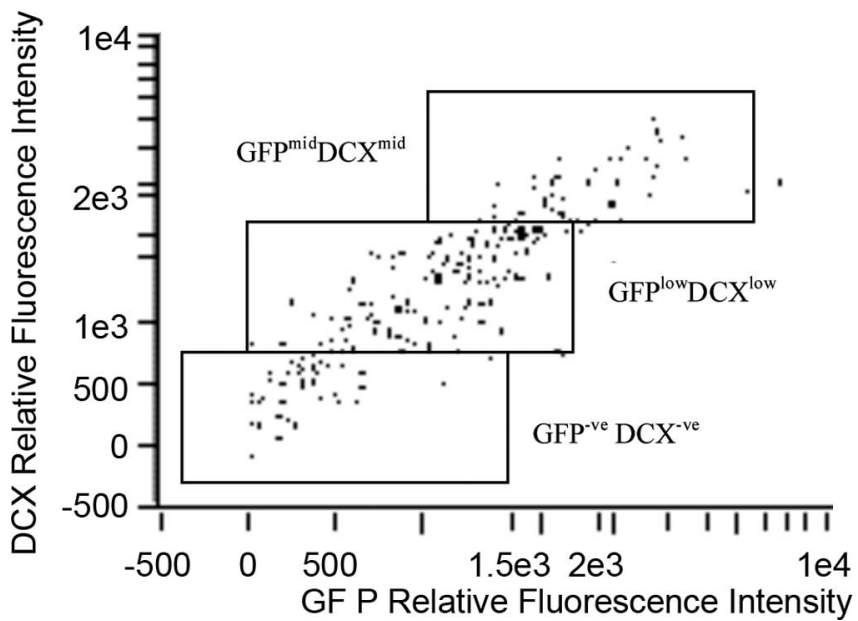

Figure 2. GFP relative fluorescence intensity correlates with DCX expression levels in individual cells. Cells from adult DCX-GFP/BAC SVZ were isolated and stained with a DCX-specific antibody. Flow cytometry analysis revealed a strong correlation between the GFP relative fluorescence intensity and the level of DCX immunostaining in individual cells. In all cases, cells that expressed GFP were also $D C X^{+}$, with no false positives being observed.
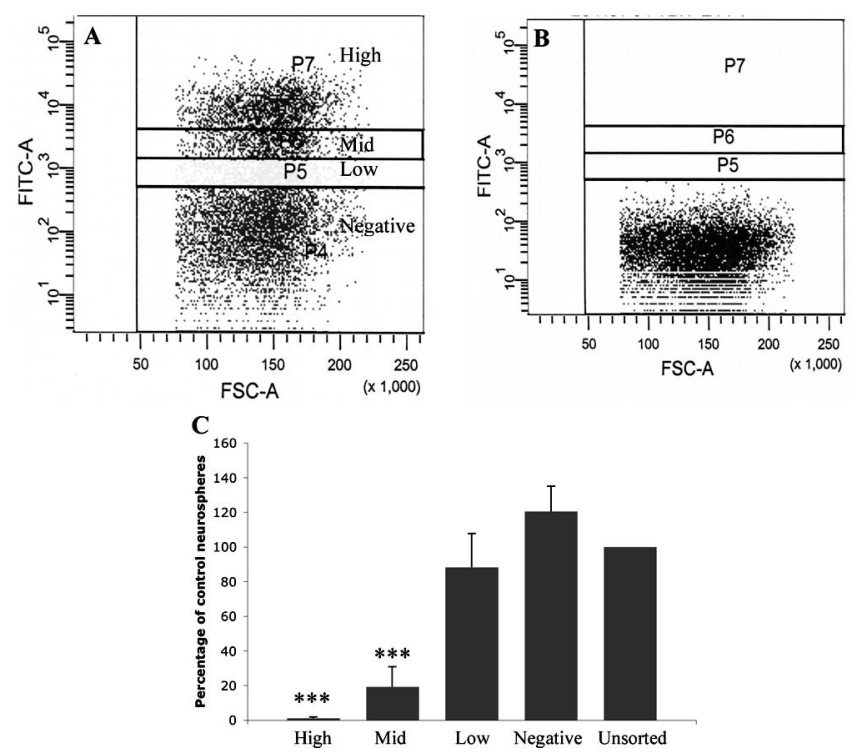

Figure 3. FACS isolation and neurosphere activity of E14 DCX-GFP/2 kb populations. $\boldsymbol{A}$, Single viable cells were isolated from E14 GFP ${ }^{+}$brains using FACS and were sorted into four populations (high, mid, low, and negative) based on DCX expression. $\boldsymbol{B}$, Unsorted cells from a wild-type littermate were collected as a control. $C$, The DCX ${ }^{\text {low }}$ population was enriched for neurosphere formation, whereas the number of neurospheres grown from the $D C X$ mid population was significantly reduced. Virtually no neurospheres were detected in the DCX high population ( ${ }^{* * *} p<0.001 ; n=4$ when compared with unsorted control). FSC, Forward scatter (cell size).

from a wild-type littermate were run through the flow cytometer as a control (Fig. 3B).

To assess the percentages of freshly isolated E14 $\mathrm{DCX}^{+}$cells that were already expressing cell type-specific markers or were proliferating, these cells were stained with antibodies directed against $\beta$ III-tubulin, MAP2, neuronal-specific nuclear protein $(\mathrm{NeuN})$, nestin, and Ki-67 and analyzed by FACS. Of the DCXhigh population, $99.9 \%$ of cells coexpressed the neuronal marker $\beta$ III-tubulin, whereas $82 \%$ expressed MAP2. Consistent with this differentiated phenotype, a very low percentage of E14 DCX ${ }^{+}$ cells were mitotically active, with only $1 \%$ of $\mathrm{DCX}^{+}$cells coex- pressing the proliferation marker Ki-67. There was some colabeling of DCX with nestin ( $\sim 20 \%$ of E14 DCX ${ }^{+}$cells); however, this only occurred in the E14 DCX ${ }^{\text {low }}$ population, with no such colabeling seen in the E14 DCX ${ }^{\text {high }}$ cells. No obvious staining of any E14 population was observed with NeuN.

To study the precursor potential of the different populations, cells were collected and plated at 500 cells per well in neurosphere-supporting medium, and the number of neurospheres generated in each condition was counted after $7 \mathrm{~d}$. The E14 DCX ${ }^{\text {high }}$ population from the DCX-GFP/ $2 \mathrm{~kb}$ line contained virtually no cells capable of forming neurospheres $(0.03 \pm 0.02$ spheres/500 cells). The $\mathrm{DCX}^{\mathrm{mid}}$ population contained some neurosphere-forming cells ( $0.39 \pm 0.18$ spheres $/ 500$ cells), but the number was considerably lower than for unsorted cells ( $2.61 \pm 0.7$ spheres/500 cells) or the DCX ${ }^{\text {low }}$ population $(2.1 \pm$ 0.28 spheres/500 cells), which both had a similar frequency of neurosphere-forming cells (Fig. 3C). Similar results were obtained using the DCX-GFP/BAC transgenic line [DCX ${ }^{\text {high }}, 0.025 \pm 0.005$ spheres/500 cells; DCX ${ }^{\text {mid }}, 0.06 \pm 0.001$ spheres/500 cells; DCX ${ }^{\text {low }}$, $0.18 \pm 0.001$ spheres $/ 500$ cells; DCX-negative $\left(\mathrm{DCX}^{-}\right), 0.08 \pm$ 0.002 spheres $/ 500$ cells; unsorted, $0.11 \pm 0.007$ spheres $/ 500$ cells] (supplemental Fig. 1, available at www.jneurosci.org as supplemental material).

To determine whether the precursors that gave rise to neurospheres had stem cell-like (self-renewal) properties, neurospheres generated from the sorted E14 DCX ${ }^{\text {mid }}$, DCX $^{\text {low }}$, and DCX $^{-}$cell populations, as well as from unsorted cells, were passaged as bulk cultures for at least 12 passages. This resulted in a 10 - to 40 -fold expansion between passages, consistent with some of the precursors having stem cell-like properties. In addition, during differentiation, neurospheres derived from all populations contained both neurons and astrocytes.

\section{$\mathrm{DCX}^{+}$cells from P2 brains have lower levels of expression and higher multipotential precursor activity than those from E14 brains}

At $\mathrm{P} 2, \mathrm{DCX}^{+}$cells comprise $\sim 30 \%$ of the total brain cell population. For additional experiments, the $\mathrm{P} 2$ population from whole brain was divided into $\mathrm{DCX}^{+}$and $\mathrm{DCX}^{-}$cells. The levels of GFP expression at $\mathrm{P} 2$ were comparable with those obtained in the E14 $\mathrm{DCX}^{\mathrm{mid}}$ and $\mathrm{DCX}^{\text {low }}$ populations. In contrast to our findings in the embryo, in which there is a significant level of colocalization of DCX and neuronal markers, only $6 \%$ of the $\mathrm{DCX}^{+}$cells in the postnatal brain expressed $\beta$ III-tubulin, whereas $13 \%$ expressed MAP2. Similar to what was found at E14, at P2 a very low percentage of $\mathrm{DCX}^{+}$cells were mitotically active, with only $1 \%$ of $\mathrm{DCX}^{+}$cells coexpressing the proliferation marker Ki-67. At P2, $\sim 6 \%$ of $\mathrm{DCX}^{+}$cells were positive for NeuN, a marker of more mature neurons.

P2 DCX ${ }^{+}$cells from whole brains had only mid to low levels of DCX expression but a higher neurosphere-forming frequency than unsorted cells $(175 \%$; mean of $28.6 \pm 4.9$ vs $16.5 \pm 3.1$ spheres/500 cells). The neurosphere-forming frequency was higher in both of these conditions than in the $\mathrm{DCX}^{-}$population (mean of $16.2 \pm 1.4$ spheres/500 cells) (Fig. $4 A$ ). The higher expressing cells from the $\mathrm{P} 2$ whole brain ( DCX $^{\text {mid }}$ ), however, had a lower neurosphere-forming frequency (mean of $6.2 \pm 4.2$ spheres/500 cells) than the DCX ${ }^{\text {low }}$ population (mean of $19.4 \pm$ 10.2 spheres/500 cells) (Fig. $4 B$ ). Once again, similar results were seen using the DCX-GFP/BAC line (DCX ${ }^{\text {mid }}, 2.34 \pm 0.38$ spheres/ 500 cells; DCX $^{\text {low }}, 4.44 \pm 1.7$ spheres/500 cells; DCX $^{-}, 0.22 \pm 0.06$ spheres/500 cells; unsorted, $2.6 \pm 0.42$ spheres/500 cells) (supplemental Fig. $1 B$, available at www.jneurosci.org as supplemental ma- 
terial). When the $\mathrm{DCX}^{+}$cells were stained with PSA-NCAM, cells coexpressing both markers had a significantly higher neurosphere-forming frequency (mean of $15.21 \pm 3.8$ spheres/500 cells) than the cells negative for these proteins (mean of $4.31 \pm 0.7$ spheres $/ 500$ cells). Unsorted cells that stained PSA$\mathrm{NCAM}^{+}$also showed significantly higher neurosphere-forming frequency (mean of $9.9 \pm 9.6$ spheres/500 cells) than the PSA-NCAM $^{-}$population (mean of $3.7 \pm 1.0$ spheres/500 cells).

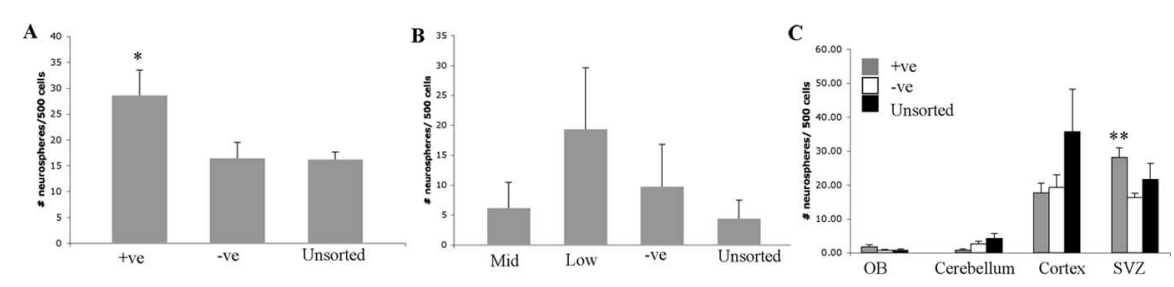

Figure 4. Neurosphere activity of $P 2 D C X^{+}$cells. $\boldsymbol{A}$, Higher neurosphere-forming activity was observed in the $D C X^{+}$population from whole P2 DCX-GFP/2 kb brains compared with DCX ${ }^{-}$and unsorted cells $(n=3)$. $\boldsymbol{B}$, Within this $D C X^{+}$population, however, the higher expressing cells ( $D C X^{\text {mid }}$ ) had a lower neurosphere-forming frequency compared with the cells with lower (DCX ${ }^{\text {low }}$ ) expression $(n=2)$. C, Overall, the $P 2$ cerebellum had relatively high levels of $D C X$ expression and was the only region in which a significantly higher number of neurospheres was observed in the $D C X^{\text {low }}$ cells compared with the $D C X^{-}$population $\left({ }^{*} p<0.05 ; n=3\right) 0 B$, Olfactory bulb.

\section{A small population of $\mathrm{DCX}^{\text {high }}$ cells are found in $\mathrm{P} 2$ cerebellum}

To further characterize which brain region contained the most $\mathrm{DCX}^{+}$cells at $\mathrm{P} 2, \mathrm{GFP}^{+}$brains were removed and various regions (olfactory bulb, cerebellum, cortex, and SVZ) were dissected. DCX ${ }^{+}$cells accounted for $\sim 1 \%$ of the total number of cells in the P2 olfactory bulb, $8 \%$ of cells in the cortex, $16 \%$ of cells in the cerebellum, and $2 \%$ of cells in the SVZ. The cerebellum contained a DCX ${ }^{\text {high }}$ population, with cells over an order of magnitude brighter than those in the other regions. The $\mathrm{DCX}^{+}$cells in the SVZ and olfactory bulb only expressed relatively low levels of GFP. Neurosphere assays revealed that $\mathrm{DCX}^{+}$cells from the cerebellum had a higher neurosphere-forming frequency (1.7 \pm 0.6 spheres $/ 500$ cells) than that of the unsorted cerebellum cells $(0.9 \pm 0.6$ spheres $/ 500$ cells) (Fig. $4 C)$. However, the precursor activity of the DCX ${ }^{\text {high }}$ cells from the cerebellum $(\sim 3 \%$ of the total population) was only $3.4 \pm 1.6 \%$ of that of the $\mathrm{DCX}^{\text {low }}$ population (Fig. 5). The DCX ${ }^{\text {mid-low }}$ cells in the olfactory bulb $(0.8 \pm 0.3$ spheres/500 cells) and cortex (17.6 \pm 2.9 spheres $/ 500$ cells) also had similar neurosphere activity to the corresponding DCX $^{-}$and unsorted cells (Fig. 4C). An increase in neurosphere activity was also observed in the SVZ, which displayed a 1.5- to 2 -fold increase in neurospheres in the DCX $^{\text {low }}$ population (28.0 \pm 2.9 spheres/500 cells) when compared with the DCX ${ }^{-}$ cells (16.2 \pm 1.2 spheres/500 cells) (Fig. $4 C)$.

\section{DCX $^{\text {low }}$ cells in the adult SVZ and hippocampus show high precursor activity, whereas DCX ${ }^{\text {high }}$ cells from the olfactory bulb have low precursor activity}

In the adult SVZ and hippocampus, cells express low levels of DCX, with these DCX-expressing cells comprising 25\% of the total cell population. For neurosphere assays, $\mathrm{DCX}^{\text {low }}$ and $\mathrm{DCX}^{-}$ cells were collected from the DCX-GFP/BAC transgenic line. $\mathrm{DCX}^{\text {low }}$ cells from the SVZ region had a similar neurosphereforming activity to that of the $\mathrm{DCX}^{-}$and unsorted populations (Fig. 6A), whereas the DCX ${ }^{\text {low }}$ cells from the hippocampus had a significantly higher neurosphere-forming activity than the $\mathrm{DCX}^{-}$and unsorted populations (Fig. $6 \mathrm{~B}$ ). The adult olfactory bulb had both the highest level of DCX expression and the most $\mathrm{DCX}^{+}$cells $\left(\sim 70 \%\right.$ of total olfactory bulb cells were $\left.\mathrm{DCX}^{+}\right)$. The DCX $^{\text {high }}$ cells in the olfactory bulb had a lower neurosphere-forming frequency than the $\mathrm{DCX}^{\text {low }}$ and $\mathrm{DCX}^{-}$populations (Fig. 7A,B).

\section{Membrane electrical properties of $\mathrm{DCX}^{+}$cells in E14 and P2 mouse brain}

To determine whether the DCX ${ }^{\text {high }}$ cells that uniformly expressed $\beta$ III-tubulin also had the electrical properties of neurons, we performed whole-cell patch-clamp recordings in slices from E14 and P2 forebrains. DCX ${ }^{\text {high }}$ cells were investigated from the

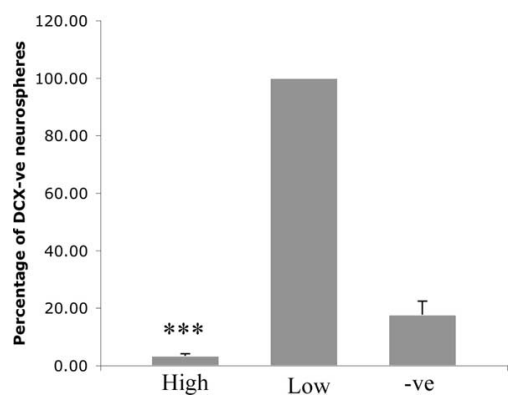

Figure 5. Neurosphere activity of $P 2$ cerebellum cells. The $D C X{ }^{\text {high }}$ cells in the $P 2 D C X-G F P / 2$ $\mathrm{kb}$ cerebellum had a significantly lower neurosphere-forming frequency then the $D C X^{-}$cells in this region $\left({ }^{* * *} p<0.001 ; n=4\right)$, whereas the $D C X^{\text {low }}$ population was enriched for neurosphere-forming cells.
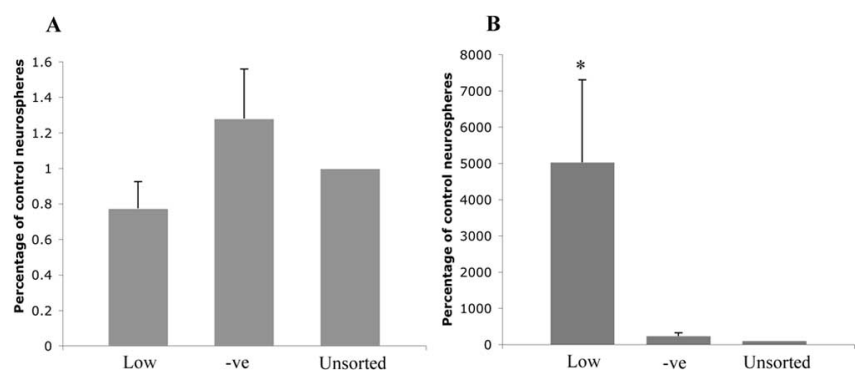

Figure 6. $\quad A, B$, Precursor properties of $D C X^{+}$cells from the adult SVZ $(A)$ and hippocampus $(B)$ of the DCX-GFP/BAC strain. $\boldsymbol{A}$, Neurosphere assays revealed that neurosphere-forming frequency of the $D C X^{\text {low }}$ population in the adult SVZ was similar to that of the $D C X^{-}$population $(n=4)$. $B$, The $D C X^{\text {low }}$ population in the adult hippocampus had a significantly higher neurosphere-forming frequency than the $D C X^{-}$and unsorted populations ( ${ }^{*} p<0.05 ; n=4$ ).

E14 cortices and DCX ${ }^{\text {mid }}$ cells from P2 cortices. Interestingly, almost all of the DCX ${ }^{\text {high }}$ cells in the E14 cortex were round and lacked processes, whereas most of the DCX ${ }^{\text {mid }}$ cells in $\mathrm{P} 2$ cortex had bipolar radial processes. As shown in Figure $8 A$, DCX ${ }^{\text {high }}$ cells from E14 cortical slices had the following resting membrane properties: RMP of $-46.4 \pm 3.2 \mathrm{mV}$ and $R_{\text {in }}$ of $1533 \pm 304 \mathrm{M} \Omega$ $\left(n=18\right.$; mean \pm SEM). Compared with DCX ${ }^{\text {high }}$ cells in E14 mice, DCX $^{\text {mid }}$ cells in P2 mice had an equivalent mean RMP of $-46.8 \pm 2.2 \mathrm{mV}$ and lower mean $R_{\text {in }}$ of $634 \pm 117 \mathrm{M} \Omega(n=24)$. Changes in membrane potential of $\mathrm{DCX}^{+}$cells in response to current injection were examined under current-clamp conditions. Almost none of the E14 DCX ${ }^{\text {high }}$ cells studied (only 1 of 18 cells) exhibited an action potential (overshoot positive to $0 \mathrm{mV}$ ) in response to depolarizing current injection (Fig. $8 \mathrm{~B}$ ). Although a similar small population of the P2 DCX ${ }^{\text {mid }}$ cells ( 2 of 24 cells) exhibited a clear action potential (Fig. $8 C$ ), an additional three cells exhibited an immature action potential (a distinguishable 

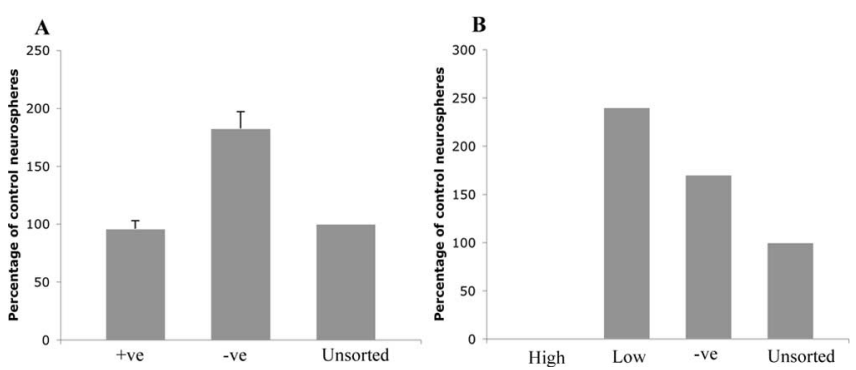

Figure 7. Precursor properties of $D C X^{+}$cells in the adult DCX-GFP/BAC olfactory bulb. The olfactory bulb had the highest levels of $D C X$ expression in the adult brain. $A$, This $D C X^{+}$population had a lower neurosphere-forming frequency than the $D C X^{-}$population. $B, 0$ f this $D C X^{+}$ population, the $D C X^{\text {high }}$ cells had no neurosphere activity, whereas the $D C X^{\text {low }}$ cells were enriched for neurosphere formation.

spike but no overshoot). Nevertheless, the majority of the population was neuronally immature, non-excitable cells. To examine depolarization-activated membrane currents, cells were held at $-60 \mathrm{mV}$, and ionic currents were elicited by depolarizing step pulses under voltage-clamp conditions. All of the E14 DCX ${ }^{\text {high }}$ and P2 DCX ${ }^{\text {mid }}$ cells examined exhibited a persistent outward current with or without a transient inward current (Fig. 9A). As shown in Figure 9B, the transient inward current was completely inhibited by $300 \mathrm{nM}$ tetrodotoxin (TTX), indicating an $\mathrm{Na}^{+}$ channel current. Interestingly, TTX also enhanced the persistent outward current, suggesting that the TTX-sensitive current of $\mathrm{DCX}^{+}$cells was a combination of a well defined transient component and a persistent inward component (Fig. 9Bii,Biv). Tetraethylammonium mostly suppressed the persistent outward current, suggesting that it was mediated by a $\mathrm{K}^{+}$channel current. Analysis of current-voltage relationships indicated that cells were divided into two groups based on the magnitude of transient inward $\mathrm{Na}^{+}$current densities. There were two distinguishable populations, particularly in $\mathrm{P} 2 \mathrm{DCX}^{\mathrm{mid}}$ cells: those exhibiting inward $\mathrm{Na}^{+}$current densities $<10 \mathrm{pA} / \mathrm{pF}$ and those with $\mathrm{Na}^{+}$ current densities $>10 \mathrm{pA} / \mathrm{pF}$. The size of the two populations for both $\mathrm{E} 14$ and $\mathrm{P} 2 \mathrm{DCX}^{+}$cells was similar (Fig. 9C,D). Together, both E14 DCX ${ }^{\text {high }}$ and P2 DCX ${ }^{\text {mid }}$ cells represented mixed neuronal progenitor populations in terms of their membrane electrical properties. P2 DCX ${ }^{\text {mid }}$ cells exhibited greater diversity with regard to action potential characteristics and transient $\mathrm{Na}^{+}$current; however, in both cases, approximately half of the cells exhibited immature neuronal differentiation with small $\mathrm{Na}^{+}$current density.

\section{Membrane electrical properties of $\mathrm{DCX}^{+}$cells in adult mouse brain}

DCX $^{\text {low }}$ cells without any processes in the adult SVZ exhibited a mean RMP of $-25.4 \pm 1.6 \mathrm{mV}$ and a high mean $R_{\text {in }}$ of $2993 \pm$ $506 \mathrm{M} \Omega(n=10)$ (Fig. 10A). These cells also failed to produce an action potential in response to current injection (Fig. 10C). In contrast, process-bearing DCX ${ }^{\text {low }}$ cells located in the subgranular zone or inner granule cell layer of the adult dentate gyrus exhibited a significantly more hyperpolarized mean RMP of $-75.1 \pm$ $10.0 \mathrm{mV}$ and lower $R_{\text {in }}$ of $825 \pm 139 \mathrm{M} \Omega(n=12)$ (Fig. $\left.10 A\right)$ compared with those observed in the SVZ. A single action potential was elicited in 2 of $12 \mathrm{DCX}^{\text {low }}$ cells in the dentate gyrus (Fig. $10 \mathrm{~B}, \mathrm{C})$ in response to current injection. All $\mathrm{DCX}^{-}$granule cells (nonlabeled cells) in the dentate gyrus recorded as a control from the same slice preparations exhibited single or repetitive action potentials (Fig. $10 B, C$ ). Voltage-gated $\mathrm{Na}^{+}$and $\mathrm{K}^{+}$currents were also examined in DCX ${ }^{\text {low }}$ cells in the SVZ and dentate gyrus.
As shown in Figure $10 D$, all examined DCX ${ }^{\text {low }}$ cells in the SVZ exhibited only marginal inward $\mathrm{Na}^{+}$current densities $(<10 \mathrm{pA} /$ $\mathrm{pF}$ ) in accordance with cells not exhibiting an action potential. Outward $\mathrm{K}^{+}$current densities obtained from these cells were also less pronounced. In contrast, the majority ( 7 of 11 cells) of DCX${ }^{\text {low }}$ cells in the dentate gyrus exhibited large $\mathrm{Na}^{+}$current densities $(>10 \mathrm{pA} / \mathrm{pF})$, whereas the remainder had small $\mathrm{Na}^{+}$current densities, indicating substantial diversity of the cell population in terms of $\mathrm{Na}^{+}$current densities (Fig. 10E). Outward $\mathrm{K}^{+}$current densities of DCX ${ }^{\text {low }}$ cells in the dentate gyrus were independent of their $\mathrm{Na}^{+}$current densities and were larger than those observed in DCX ${ }^{\text {low }}$ cells in the SVZ.

\section{Discussion}

The value of DCX as a marker of migrating neuronal precursor cells both during development and in adult neurogenic regions has been well documented (Cooper-Kuhn and Kuhn, 2002; Brown et al., 2003; Rao and Shetty, 2004). However, until now, the expression of DCX in relation to progenitor and stem cell activity has not been thoroughly investigated. Before the present study, the precise potential of $\mathrm{DCX}^{+}$cells has been difficult to investigate directly because of the intracellular nature of the DCX protein. This has restricted both the isolation of $\mathrm{DCX}^{+}$cells by flow cytometry for in vitro studies and the ability to record electrophysiologically from these cells both in slice preparations and in situ. To overcome this, we used two transgenic mouse lines expressing GFP under the control of the DCX promoter.

The GFP expression pattern in both transgenic lines coincided with native DCX protein expression when examined immunohistochemically, a fact we confirmed using flow cytometric analysis of individual cells. Crucially, the latter demonstrated that the expression of GFP accurately reflects that of DCX, even at low levels. This was of particular importance in defining the DCX ${ }^{\text {low }}$ population that we found to contain multipotential precursor activity. Both lines gave similar findings in relation to the association of DCX levels to neuronal and multipotential precursor activity, the only difference being that the transgenic line in which GFP was driven off the $2 \mathrm{~kb}$ DCX promoter region lacked GFP expression in the adult brain. The finding that adult DCX expression is driven differentially to that of the embryo and early postnatal animal is of particular interest. A previous study identified several putative transcription factor binding sites in the $3.5 \mathrm{~kb}$ DCX regulatory region studied (Karl et al., 2005). Many of these binding sites, including Brn-2, NeuroD1, E2F-1, and E2F-2, are known to be involved in neuronal development. Although the promoter region we used in the DCX-GFP/2 kb line contained most of these transcription factor binding sites, one potential binding site identified previously farther upstream was not included. The absence of the E2F-1 binding site in our DCX-GFP/2 $\mathrm{kb}$ transgenic mice could potentially lead to a decrease in the expression of GFP in the adult, because mice bearing a targeted deletion of E2F-1 have been shown to have reduced neurogenesis in the adult CNS, whereas the numbers of neurons in the neocortex, which develops exclusively during embryogenesis, is unchanged (Cooper-Kuhn and Kuhn, 2002). In contrast, the DCXGFP transgenic line generated using the BAC construct uses a large genomic region upstream of the DCX gene to drive GFP expression, and therefore this promoter is likely to contain all of the elements required for faithful expression of the GFP protein.

It has been widely accepted that cells expressing high levels of DCX are neuronally committed (Brown et al., 2003). The most surprising finding from the present flow cytometry studies was, therefore, that the $\mathrm{DCX}^{+}$cell population contained not only cells 
restricted to the neuronal lineage but also a sizeable population of neurosphereforming precursors that had the hallmarks of stem cells: self-renewal and multipotentiality. Furthermore, these two types of cells could be differentiated from each other on the basis of DCX expression levels, regardless of developmental stage or brain region. Although not expected, these findings are not incompatible with previous reports, which have based their conclusion on results obtained in immunohistochemically processed tissue in which only cells expressing relatively high levels of DCX can be visualized. In the present study, such cells, for example the DCX high population in the E14 forebrain, were also found to be exclusively neuronal in lineage, with $99.9 \%$ expressing the neuronal marker $\beta$ III-tubulin. They also appeared to be primarily postmitotic as revealed by the low frequency of Ki-67-positive cells $(<1 \%)$. It has been shown previously that the highest levels of DCX expression are usually found in migrating neurons, suggesting an immature phenotype, which is consistent with the function of DCX as a regulator of microtubular formation (Francis et al., 1999). Electrophysiological studies using slice preparations from the E14 cortex showed that the DCX ${ }^{\text {high }}$ cells were indeed predominantly immature neuronal cells, because they had either a complete absence of $\mathrm{Na}^{+}$current or an $\mathrm{Na}^{+}$current density insufficient to produce an action potential. However, neurons were found at various stages of neuronal maturation, from those without $\mathrm{Na}^{+}$currents through those in which an action potential could be clearly identified. At P2, when developmental neuronal migration is complete and DCX expression levels are lower, the cells had increased $\mathrm{Na}^{+}$current density, as would be expected of a more mature population. Nevertheless, the $\mathrm{P} 2$ population did contain a number of more immature cells with low to absent $\mathrm{Na}^{+}$ current. These presumably reflect the neurosphere-forming precursor cells.

In adult preparations, the membrane electrical properties of $\mathrm{DCX}^{\text {low }}$ cells depended on the brain region in which they were located. The depolarized RMP and high $R_{\text {in }}$ observed for DCX ${ }^{\text {low }}$ cells in the SVZ are consistent with those reported for neuronal progenitors ( $\beta$ III-tubulin ${ }^{+}$) in the SVZ and posterior rostral migratory stream (Wang et al., 2003; Liu et al., 2005) but different from those described for $\mathrm{GFAP}^{+}$progenitors in the SVZ, which exhibit a hyperpolarized RMP of approximately $-80 \mathrm{mV}$ and low $R_{\text {in }}$ of $\sim 50 \mathrm{M} \Omega$ (Liu et al., 2005). The depolarized RMP may be attributed in part to a voltage error caused by the high $R_{\text {in }}$ as reported previously (Wang et al., 2003). None of the DCX ${ }^{\text {low }}$ cells in the SVZ exhibited an action potential or distinct $\mathrm{Na}^{+}$current densities of $>10 \mathrm{pA} / \mathrm{pF}$. The membrane electrical properties of DCX $^{\text {low }}$ cells in the dentate gyrus were significantly different from those of the DCX ${ }^{\text {low }}$ cells in the SVZ. In contrast to functionally differentiated granule cells, which exhibit repetitive action potentials in response to depolarizing current injection, only $17 \%$ of the $\mathrm{DCX}^{\text {low }}$ cells elicited an action potential. Together with the variation in $\mathrm{Na}^{+}$current densities in these cells, DCX ${ }^{\text {low }}$ cells in the dentate gyrus appear to represent early to intermediate
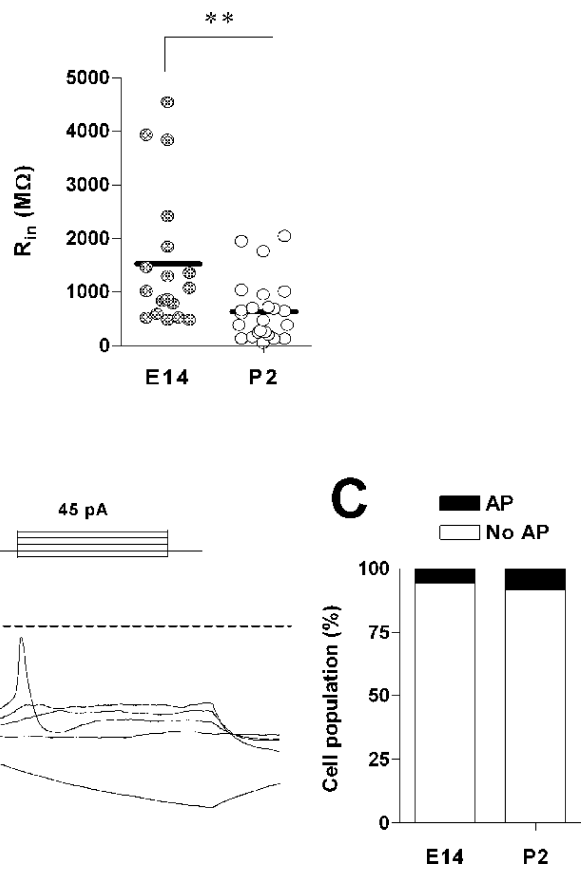

$100 \mathrm{~ms}$

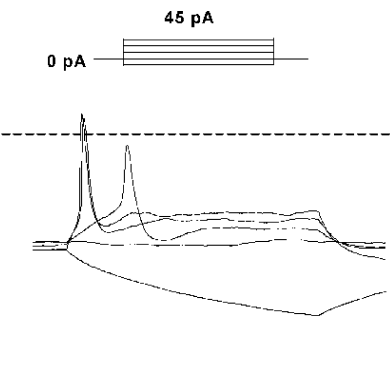

E14

P2

Figure 8. Electrical properties of cortical DCX ${ }^{+}$cells in acute forebrain slices of E14 and P2 DCX-GFP/2 kb mice. $A$, Scatter plots of RMP and $R_{\text {in }}$ of cortical E14 $(n=18)$ and P2 $(n=24) D C X^{+}$cells. Asterisks denote a significant difference between E14 and P2 ups (** $p<0.01) . B$, Representative traces of voltage responses to current injection in two different $D C X^{+}$cells. Examples of graphs of normalized populations of E14 $(n=18)$ and P2 $(n=24)$ cells in which an action potential (exhibiting an overshoot positive to $0 \mathrm{mV}$ ) either could or could not be evoked.

stage neuronal progenitors, similar to $\mathrm{DCX}^{\text {mid }}$ cells in the P2 cortex. In contrast, DCX ${ }^{\text {low }}$ cells in the SVZ comprise a relatively uniform population of early stage neuronal progenitors.

As outlined above, the finding that the DCX ${ }^{\text {low }}$ population contained a significant number of neural stem-like cells that gave rise to neurospheres, which could be subsequently passaged extensively and shown to differentiate into multiple neural types, was unexpected. Even more surprising was the finding that, in the P2 ventricular zone and cerebellum, as well as in the adult SVZ, hippocampus, and olfactory bulb, the DCX ${ }^{\text {low }}$ population contained a significant number of neurospheres compared with the $\mathrm{DCX}^{-}$population. Although it has been reported previously that there is a population of $\mathrm{DCX}^{+}$cells in the dentate gyrus and the SVZ that expresses the proliferation marker Ki-67 (Brown et al., 2003), these cells were not thought to be multipotential precursors because there was no colocalization of DCX with nestin or GFAP (Couillard-Despres et al., 2005). Our results, however, demonstrate the expression of nestin in $20 \%$ of DCX ${ }^{\text {low }}$ cells at E14, further reflecting the stem-like nature of some of these cells. These results suggest that many of the DCX ${ }^{\text {low }}$ cells are not, as previously thought, committed to the neuronal lineage but are in fact multipotential neural precursors. The fact that these cells could be repeatedly passaged over 10 generations further suggests that they are not restricted in their self-renewal capacity. Whether most of the stem cells in the brain go through a stage of DCX expression before final commitment to the neuronal lineage or whether this represents an entirely separate precursor population remains to be resolved. However, the fact that these cells are found in many brain regions at many stages of development suggests that this is an important subpopulation that requires additional characterization.

The presence of neurosphere-forming cells in the cerebellum within the $\mathrm{DCX}^{\text {low }}$ population contradicts the findings of a pre- 
A
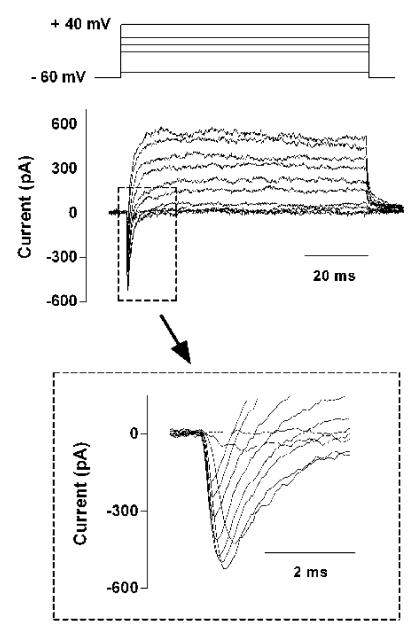

Transient inw ard current
B

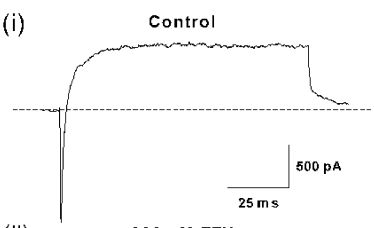

(ii)

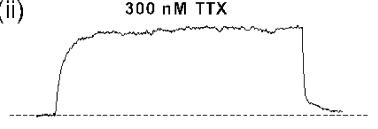

(iii) $300 \mathrm{nM} \mathrm{TTX}+10 \mathrm{mM}$ TEA

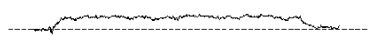

(iv) TTX-sensitive $\mathrm{Na}^{+}$current

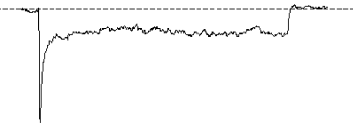

(v) TEA-sensitive $\mathrm{K}^{+}$current

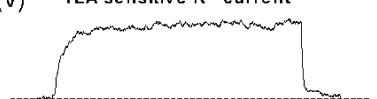

C $\quad \mathrm{E} 14$

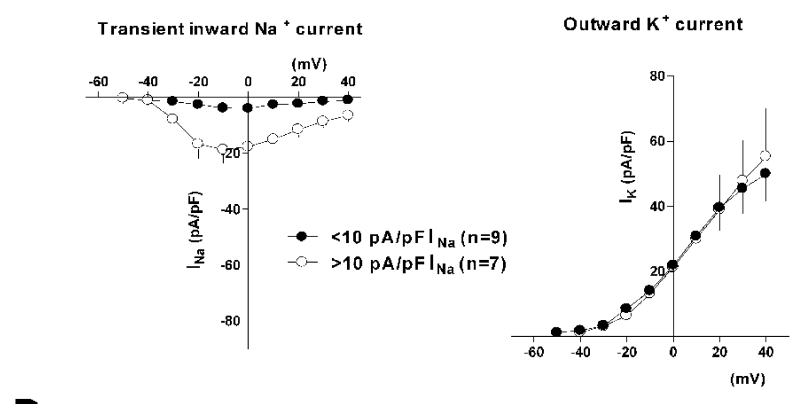

D P2

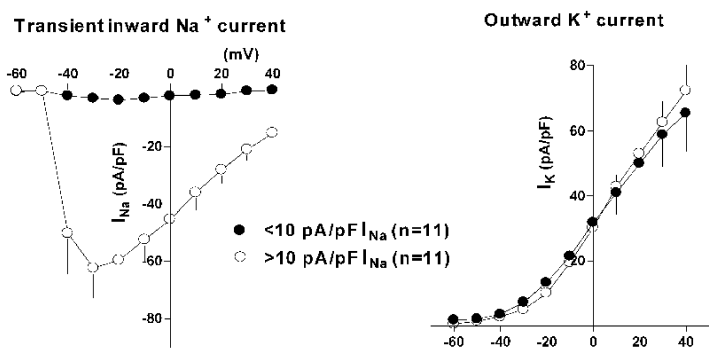

Figure 9. Depolarization-activated whole-cell currents recorded from cortical $D C X^{+}$cells of E14 and P2 DCX-GFP/2 kb mice. $A$, Representative family of membrane currents recorded from a P2 $D C X^{\text {mid }}$ cell in response to depolarizing voltage steps. Holding potential, $-60 \mathrm{mV}$. Inset, Transient inward currents displayed at higher gain. $B$, Membrane currents recorded from a P2 DCX mid cell in response to a voltage step from -60 to $0 \mathrm{mV}$ in the absence (i) and presence (ii) of $300 \mathrm{~nm} \mathrm{TTX} \mathrm{and} 300 \mathrm{~nm}$ TTX plus $10 \mathrm{~mm}$ TEA (iii). A TTX-sensitive Na ${ }^{+}$channel current trace (iv) was obtained by subtracting traces (i) and (ii). Similarly, a tetraethylammonium (TEA)-sensitive $\mathrm{K}^{+}$channel current trace (v) was obtained by subtracting traces (ii) and (iii). C, D, Current-voltage (I-V) relationships obtained for transient inward $\mathrm{Na}^{+}$current and persistent outward $\mathrm{K}^{+}$current in cortical E14 and P2 DCX ${ }^{+}$cells. Cells were divided into two groups based on their maximum inward current densities: those exhibiting currents $<10 \mathrm{pA} / \mathrm{pF}(\bigcirc)$ and those with transient inward currents $>10 \mathrm{pA} / \mathrm{pF}(\bigcirc)$.

A

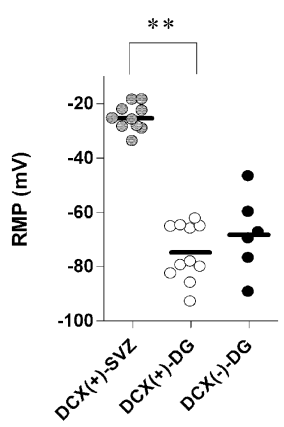

B
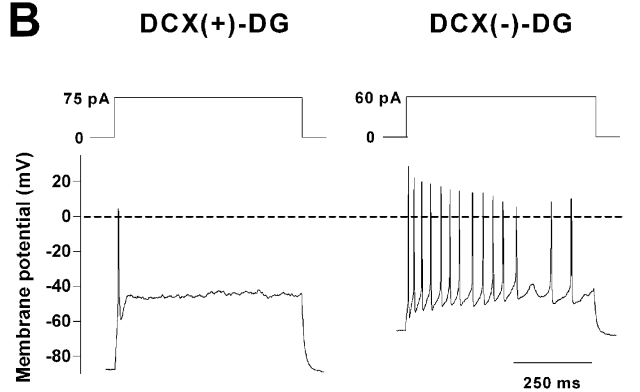
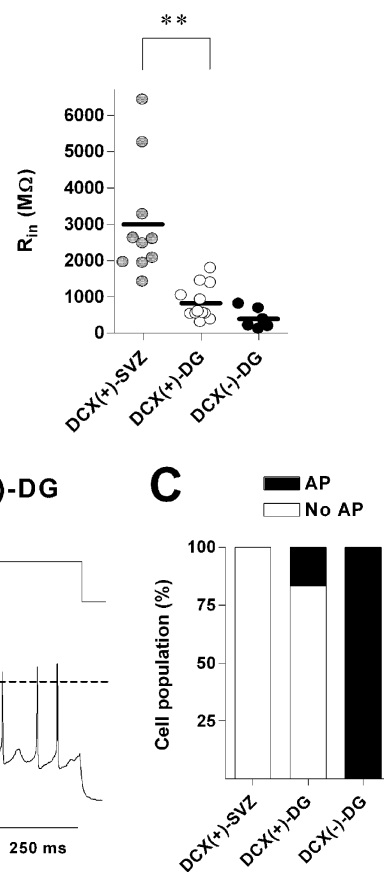

D DCX(+)-SVZ

Transient inward $\mathrm{Na}^{+}$current
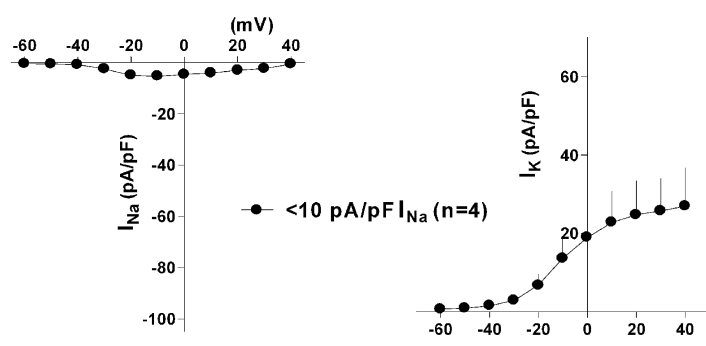

E DCX(+)-DG

Transient inward $\mathrm{Na}^{+}$current

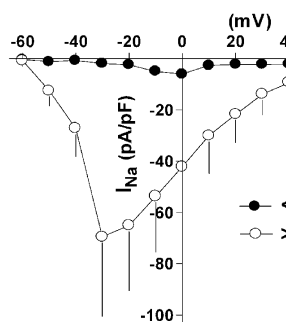

Outward $\mathrm{K}^{+}$current

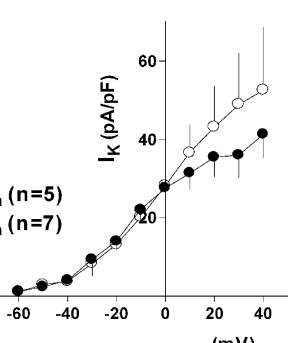

Figure 10. Passive and active electrical properties of SVZ and dentate gyrus $D C X^{\text {low }}$ cells in adult DCX-GFP/BAC brain slices. $A$, Scatter plots of RMP and $R_{\text {in }}$ of DCX ${ }^{\text {low }}$ cells in the $S V Z$ ( $n=10$ ) and the dentate gyrus (DG) $(n=12)$ and $D C X^{-}$cells in the dentate gyrus $(n=6)$. Asterisks denote a significant difference between $S V Z$ and $D G D C X^{\text {low }}$ cells $\left.{ }^{* * *} p<0.01\right)$. $B$, Representative traces of action potentials (AP) induced by current injection in $D C X^{\text {low }}$ and $D C X^{-}$cells obtained from the dentate gyrus. Examples of cells that exhibited either a single (DCX $\left.{ }^{\text {low }) ~ o r ~ r e p e t i t i v e ~(D C X ~}{ }^{-}\right)$AP. $C$, Bar graphs of normalized populations of SVZ $(n=10)$ and dentate gyrus $(n=12) D C X^{\text {low }}$ cells and dentate gyrus $(n=6) D C X^{-}$cells in which an action potential (exhibiting an overshoot positive to $0 \mathrm{mV}$ ) either was or was not evoked. $D, E$, Current-voltage relationships obtained for transient inward $\mathrm{Na}^{+}$current and persistent outward $\mathrm{K}^{+}$current at a holding potential of $-80 \mathrm{mV}$ in DCX low cells in the SVZ $(n=5)$ and the dentate gyrus $(n=11)$. Cells were divided into two groups: those exhibiting maximum inward current densities $<10 \mathrm{pA} / \mathrm{pF}(\mathbf{O})$ and those exhibiting current densities $>10 \mathrm{pA} / \mathrm{pF}(\bigcirc)$. 
vious study, which reported that the multipotential cerebellar precursor is not within the neuroblast lineage (Lee et al., 2005). In fact, our data suggest that nearly all of the stem-like cells in the cerebellum reside in the DCX ${ }^{\text {low }}$ population. This discrepancy does not appear to be attributable to different markers being used to define the neuronal lineage cells, because we show here that PSA-NCAM, one of the markers used in the aforementioned study to exclude neuronal lineage cells, was found to be coexpressed with DCX on a large proportion of the neurosphereforming cells from the postnatal brain. One possible explanation of this discrepancy is that the previous study excluded all cells expressing Math-1 (mouse atonal homolog 1), so it would be interesting to determine whether this population contained the DCX $^{\text {low }}$, PSA-NCAM ${ }^{+}$stem cells.

The adult olfactory bulb contained DCX ${ }^{\text {high }}$ cells, which have been reported previously to be the granular and periglomerular neurons (Nacher et al., 2001). However, although this could suggest recent migration into the bulb, such an assumption is not consistent with the observation of lower levels of DCX in the rostral migratory stream. One possibility is that DCX, because of its role in regulating cytoskeletal changes, is involved in the neural plasticity occurring in the olfactory bulb, including neurite outgrowth and synaptogenesis (Nacher et al., 2001). However, this seems unlikely because DCX is absent from regions such as the hypothalamus, in which continuous synaptic reorganization occurs and other markers of synaptic plasticity, such as PSANCAM, are expressed (Alonso et al., 1997).

In summary, this study has allowed us to divide $\mathrm{DCX}^{+}$cells in the brain into two distinct subpopulations based on their level of DCX expression. DCX ${ }^{\text {high }}$ cells, regardless of location, are restricted to the neuronal lineage or are bone fide neurons, whereas some DCX ${ }^{\text {low }}$ cells retain their multipotentiality. The ability to isolate pure populations of viable immature neurons from various parts of the brain at different developmental stages provides a unique source of cells for studying neuronal maturation, survival, and gene expression, as well as allowing quantification of neuronal turnover in both normal and pathological conditions.

\section{References}

Alonso G, Prieto M, Legrand A, Chauvet N (1997) PSA-NCAM and B50/ GAP-43 are coexpressed by specific neuronal systems of the adult rat mediobasal hypothalamus that exhibit remarkable capacities for morphological plasticity. J Comp Neurol 384:181-199.

Brown JP, Couillard-Despres S, Cooper-Kuhn CM, Winkler J, Aigner L, Kuhn HG (2003) Transient expression of doublecortin during adult neurogenesis. J Comp Neurol 467:1-10.

Bull ND, Bartlett PF (2005) The adult mouse hippocampal progenitor is neurogenic but not a stem cell. J Neurosci 25:10815-10821.

Cooper-Kuhn CM, Kuhn HG (2002) Is it all DNA repair? Methodological considerations for detecting neurogenesis in the adult brain. Brain Res Dev Brain Res 134:13-21.

Couillard-Despres S, Winner B, Schaubeck S, Aigner R, Vroemen M, Weidner N, Bogdahn U, Winkler J, Kuhn HG, Aigner L (2005) Dou- blecortin expression levels in adult brain reflect neurogenesis. Eur J Neurosci 21:1-14.

des Portes V, Pinard JM, Billuart P, Vinet MC, Koulakoff A, Carrie A, Gelot A, Dupuis E, Motte J, Berwald-Netter Y, Catala M, Kahn A, Beldjord C, Chelly J (1998) A novel CNS gene required for neuronal migration and involved in X-linked subcortical laminar heterotopia and lissencephaly syndrome. Cell 92:51-61.

Francis F, Koulakoff A, Boucher D, Chafey P, Schaar B, Vinet MC, Friocourt G, McDonnell N, Reiner O, Kahn A, McConnell SK, Berwald-Netter Y, Denoulet P, Chelly J (1999) Doublecortin is a developmentally regulated, microtubule-associated protein expressed in migrating and differentiating neurons. Neuron 23:247-256.

Frisen J, Johansson CB, Torok C, Risling M, Lendahl U (1995) Rapid, widespread, and long lasting induction of nestin contributes to the generation of glial scar tissue after CNS injury. J Cell Biol 131:453-464.

Gloster A, Wu W, Speelman A, Weiss S, Causing C, Pozniak C, Reynolds B, Chang E, Toma JG, Miller FD (1994) The T $\alpha$-1 $\alpha$-tubulin promoter specifies gene expression as a function of neuronal growth and regeneration in transgenic mice. J Neurosci 14:7319-7330.

Gong S, Yang X, Li C, Heintz N (2002) Homologous recombination based modification of bacterial artificial chromosomes (BACs) using novel shuttle vectors containing the R6K $\gamma$ origin of replication. Genome Res 12:1992-1998.

Gravel M, Di Polo A, Valera PB, Braun PE (1998) Four-kilobase sequence of the mouse CNP gene directs spatial and temporal expression of lacZ in transgenic mice. J Neurosci Res 53:393-404.

Hannan AJ, Henke RC, Seeto GS, Capes-Davis A, Dunn J, Jeffrey PL (1999) Expression of doublecortin correlates with neuronal migration and pattern formation in diverse regions of the developing chick brain. J Neurosci Res 55:650-657.

Karl C, Couillard-Despres S, Prang P, Munding M, Kilb W, Brigadski T, Plotz S, Mages W, Luhmann H, Winkler J, Bogdahn U, Aigner L (2005) Neuronal precursor-specific activity of a human doublecortin regulatory sequence. J Neurochem 92:264-282.

Lee A, Kessler JD, Read TA, Kaiser C, Corbeil D, Huttner WB, Johnson JE, Wechsler-Reya RJ (2005) Isolation of neural stem cells from the postnatal cerebellum. Nat Neurosci 8:699-701.

Liu X, Wang Q, Haydar TF, Bordey A (2005) Nonsynaptic GABA signaling in postnatal subventricular zone controls proliferation of GFAPexpressing progenitors. Nat Neurosci 8:1179-1187.

Meyer G, Perez-Garcia CG, Gleeson JG (2002) Selective expression of doublecortin and LIS1 in developing human cortex suggests unique modes of neuronal movement. Cereb Cortex 12:1225-1236.

Nacher J, Crespo C, McEwen BS (2001) Doublecortin expression in the adult rat telencephalon. Eur J Neurosci 14:629-644.

Nolte C, Matyash M, Pivneva T, Schipke CG, Ohlemeyer C, Hanisch UK, Kirchhoff F, Kettenmann H (2001) GFAP promoter-controlled EGFPexpressing transgenic mice: a tool to visualize astrocytes and astrogliosis in living brain tissue. Glia 33:72-86.

Overstreet LS, Hentges ST, Bumaschny VF, de Souza FS, Smart JL, Santangelo AM, Low MJ, Westbrook GL, Rubinstein M (2004) A transgenic marker for newly born granule cells in dentate gyrus. J Neurosci 24:3251-3259.

Rao MS, Shetty AK (2004) Efficacy of doublecortin as a marker to analyse the absolute number and dendritic growth of newly generated neurons in the adult dentate gyrus. Eur J Neurosci 19:234-246.

Wang DD, Krueger DD, Bordey A (2003) Biophysical properties and ionic signature of neuronal progenitors of the postnatal subventricular zone in situ. J Neurophysiol 90:2291-2302. 